\title{
REVERSING BELLMAN OPERATOR INEQUALITY
}

\section{Mohammad Sababheh, Hamid Reza Moradi and Shigeru Furuichi}

Abstract. The main aim of the present paper is to obtain several reverses of the operator Bellman inequality. To this end, we employ Mond-Pečarić method to achieve a general inequality treating the arithmetic mean and unital positive linear maps. In particular, we show that, for certain scalars $\alpha, \beta$,

$$
\alpha\left(\Phi\left(I-A \nabla_{v} B\right)\right)^{1 / p}+\beta I \leqslant \Phi\left((I-A)^{1 / p} \nabla_{v}(I-B)^{1 / p}\right)
$$

for the positive operators $A, B$, the normalized positive linear map $\Phi$ and $p>1$. As a consequence, we get multiplicative and additive reverses of operator Bellman inequality. Further, we show some inequalities involving concave and convex functions. In the end, we present a simple proof of the scalar Bellman inequality and its reverses.

Mathematics subject classification (2010): 47A63, 46L05, 47A60. method.

Keywords and phrases: Operator inequalities, Bellman inequality, operator concavity, Mond-Pečarić

\section{REFERENCES}

[1] M. Bakherad And A. Morassaei, Some operator Bellman type inequalities, Indag. Math., 26 (2015), 646-659.

[2] R. Bellman, On an inequality concerning an indefinite form, Amer. Math. Monthly., 63 (1956), $108-109$.

[3] M. FujiI, J. MićIć Hot, J, PEČARIĆ And Y. SEO, Reverse inequalities on chaotically geometric mean via Specht ratio, II, J. Inequal. Pure and Appl. Math., 4(2) (2003), Article 40.

[4] T. Furuta, J. Mićić, J. PEČARić And Y. SEO, Mond-Pečarić method in operator inequalities, Element, Zagreb, 2005.

[5] F. Mirzapour, A. Morassaei And M.S. Moslehian, More on operator Bellman inequality, Quaest. Math., 37 (2014), 9-17.

[6] A. Morassaei, F. Mirzapour And M.S. Moslehian, Bellman inequality for Hilbert space operators, Linear Algebra Appl., 438 (2013), 3776-3780.

[7] S. Sheybani, M.E. OMidvar AND H.R. MorAdi, New inequalities for operator concave functions involving positive linear maps, Math. Inequal. Appl., 21(4) (2018), 1167-1174. 